\title{
Magische Ginseng-Wurzelmännchen
}

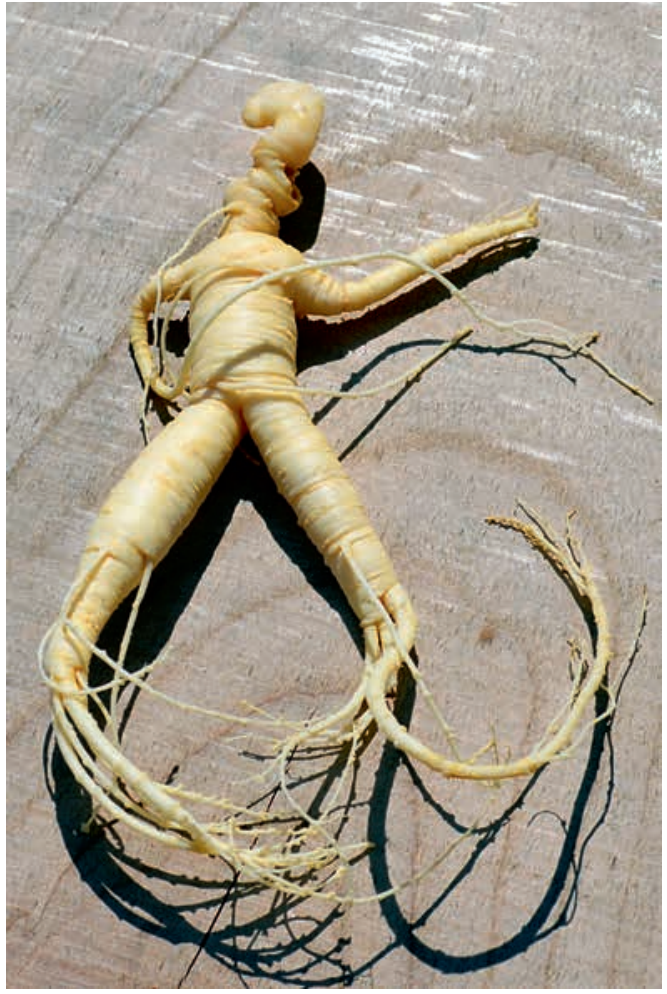

Abb. 1: „Der Faulenzer“. (Foto: FloraFarm GmbH, Walsrode)

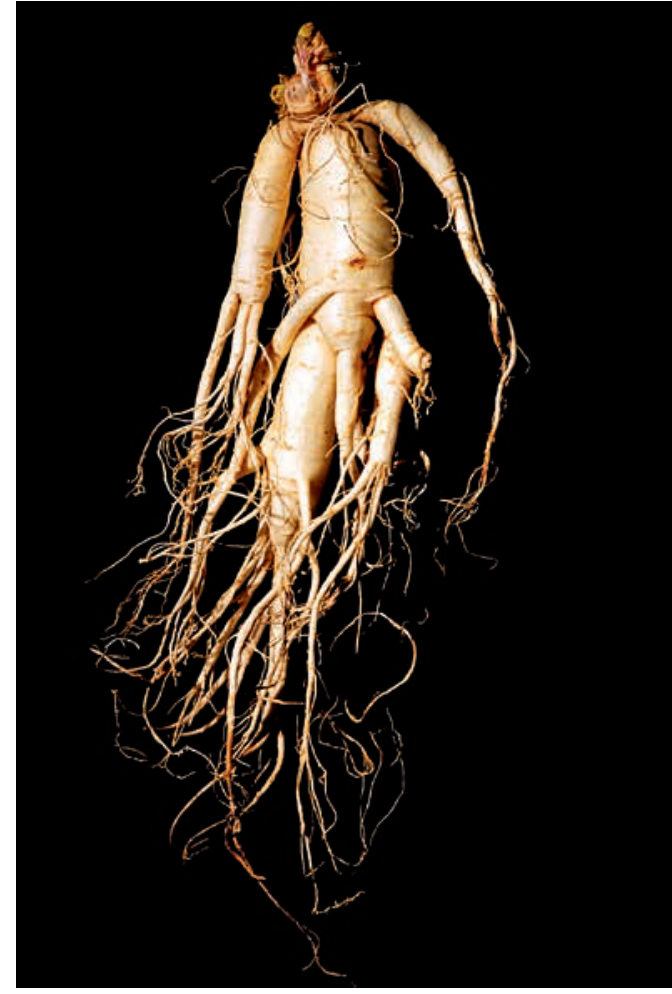

Abb. 2: „Paarbildung“. (Foto: FloraFarm GmbH, Walsrode)

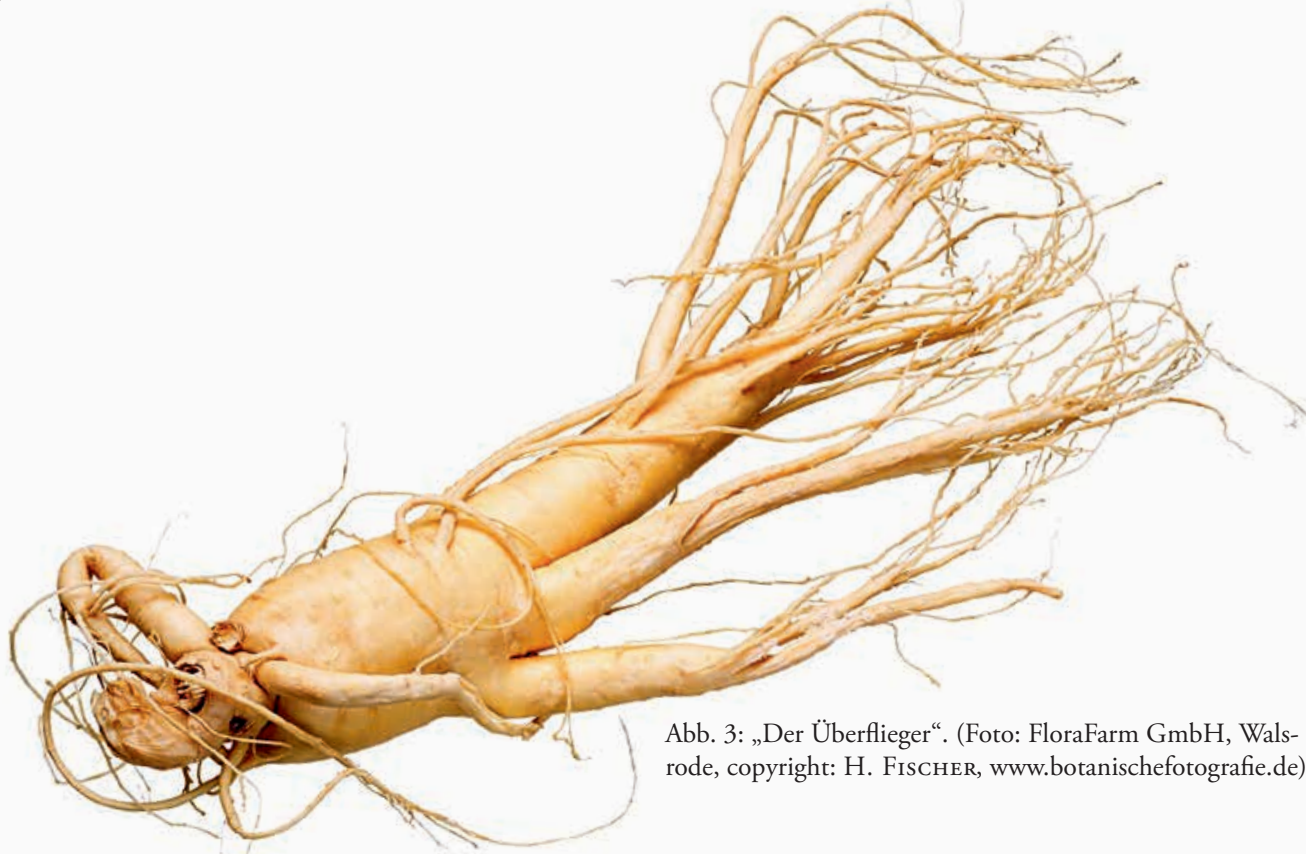

